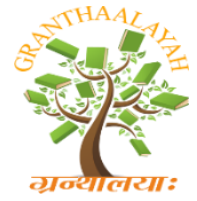
INTERNATIONAL JOURNAL OF RESEARCH - GRANTHAALAYAH
A knowledge Repository

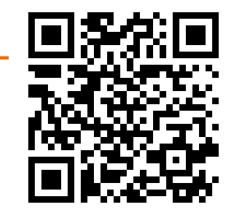
Social

\section{SCHOOL ADMINISTRATORS' UTILIZATION OF MANAGEMENT INFORMATION SYSTEM FOR ADMINISTRATIVE EFFECTIVENESS IN SECONDARY SCHOOLS IN ENUGU EDUCATION ZONE}

\author{
Thompson Chidinmachinenye ${ }^{\mathbf{1}}$, Anachuna, ObinnaNonso ${ }^{1}$ \\ ${ }^{1}$ Department of Educational Management and Policy, NnamdiAzikiwe University, Awka, \\ Anambra State
}

\begin{abstract}
The study ascertained school administrators' utilization of management information system for administrative effectiveness in secondary schools in Enugu Education Zone. Two specific purposes were formulated and two research questions guided the study. Descriptive survey design was adopted for the study. The population of the study comprised all the 31 principals in public secondary schools in Enugu education zone. A 14 items researcher developed instrument titled; School Administrators' utilization Management Information System Questionnaire (SAMISQ) was used for data collection. The instrument was structured on a four rating scale of Strongly Agree (SA), Agree (A), Disagree (D) and Strongly Disagree (SD) weighted 4, 3, 2 and 1 respectively. The instrument was face validated by three research experts. The Cronbach alpha was used to determine the reliability of the instrument which yielded a high reliability coefficient value of 0.82. Data were analyzed using mean and standard deviation. The findings revealed among others that school administrators' do not utilize management information system for students' personnel administration in secondary schools by not; allowing students to apply for admission online, processing students results using spreadsheet software, managing students attendance using spreadsheet software, disseminating information to students and parent through the school website, encouraging teachers to issue home assignment to student using email system, and encouraging multi-media instructional delivery using PowerPoint software application. Thus, the study recommended among others that the Government through the State Ministry of Education should organize seminars and workshop for secondary school administrators in order to train them on the utilization of management information system for student personnel administration. Conclusion was drawn based on the findings.
\end{abstract}

Keywords: Management Information System; School Administrators'; Administrative Effectiveness.

Cite This Article: Thompson Chidinmachinenye, and Anachuna, ObinnaNonso. (2019). "SCHOOL ADMINISTRATORS' UTILIZATION OF MANAGEMENT INFORMATION SYSTEM FOR ADMINISTRATIVE EFFECTIVENESS IN SECONDARY SCHOOLS IN ENUGU EDUCATION ZONE." International Journal of Research - Granthaalayah, 7(9), 102-109. https://doi.org/10.29121/granthaalayah.v7.i9.2019.565. 


\section{Introduction}

The complexity in administrative process in many organizations requires a modernized system approach to ease the process. The school is an institution of learning saddled with the responsibility of implementing educational policies and actualizing the goals of education. This cannot be realized without effective administration of the school. Administrative effectiveness is about steady accomplishment of administrative duties and timely realization of set objectives. Akomolafe (2012) defined administrative effectiveness as the positive response to administrative efforts and actions with the intention to accomplish stated goal. In relation to the school system, Akinola (2013) asserted that it is the extent to which the set goals or objectives of a school programme are accomplished. Administrative effectiveness can be measured trough school administrators extent of accountability, school performance improvement, curriculum improvement, effective resources management, monitoring, appropriate delegation of tasks, timely discharge of duties and constant meeting of targets (Akinfolarin, 2017). Areas in school administration include; staff personnel administration, financial management students' personnel administration, record management, maintenance of facilities among others. At the secondary tier of education, the principal is the chief administrator the school who perform multi-roles and discharges administrative and managerial tasks modern and dynamic manner. According to Ikediugwu (2016), good school managers must carefully and effectively handle educational resources particularly money, material and machines including computers, teaching technology and internal facilities put under their custody for proper management of fund. With these various function of the school administrator, Okon, Ekaette and Ameh (2015) asserted that there is no doubt that secondary education in Nigeria has become more complex over the years with concomitant management demands being exerted on the principal especially in today's Information and Communication Technology (ICT) era. Such management and administrative demands can only be carried out effectively through administrative process that is characterized by the use management information system (MIS) in the areas of organized data processing, information storage and retrieval system among others.

Management Information System is designed to assist managers in performing their work through an organized and most effective mode of information collection, processing, storage and retrieval model (Nwangwu, Ememe\&Obike, 2013). It is the application of modern technologies and computerized methods imputing, processing, storing and retrieving organizational information for effective administration. Management information system (MIS) as opined by Madiha (2013) is being used by schools to support a range of administrative activities including attendance monitoring, assessment records, reporting, financial management, and resource and staff allocation. The aspects of school administration that this study focuses on are students' personnel administration and financial management.

Student personnel administration connotes series of managerial and administrative services of school leaders and staff aimed at promoting students academic achievement. Ejeh, Okenjomand Chizi-Woko(2016) asserted that student personnel administration refers to all the activities and services that are rendered to students by school and its staff, outside the normal classroom instructions for the achievement of the educational objectives. It involves all the activities and services that are rendered to students for the achievement of the educational objectives (Akpan \& Onabe, 2016). There is a growing demand for educational services across all levels in the school system. The enormous rise in the number of students in schools as well as the multiplicity of 
programmes coupled with the complexity of administering a given secondary school have made school principals to handle large volumes of data which they must process speedily to provide information to the Ministry of Education, the school boards, the teaching and learning personnel within the precincts of the school, as well as the general public (Asiabaka, 2010). MIS is used for numeruous activities of student personnel administration which include processing admission, monitoring students' attendance in school, computation of students results, transmitting information to students and parents using email and website among others. Similarly, Benwari and Dambo (2014) asserted that other students' information ranging from their admission status, personal records, parents, address, phone numbers and email, continuous assessment records can be recorded and updated electronically. When students are giving assignments to take home, they download study packs and materials from the internet to enable them to have a wide spectrum of ideas and knowledge of the topic. Benwari and Dambo further asserted that the school management information system can be used for infrastructure and fees management, hostel space allocation and management, tracking students who have defaulted in payment of fees or other things. MIS is also used in storing and updating students' information electronically such as personal records, parents address, phone numbers and email address, continuous assessment data among others. Through the utilization of management information system, school fees payments are easily made and track online by the school management and financial fraud or default in payment is averted, hence, promoting accountability and effective financial management in the school.

The principal is the chief accounting officer of the school who is responsible for ensuring efficient management of school finance. Egwu (2016) agree that managing funds is one of the major tasks of principals. Similarly, Alia and Iwuoha (2014) posited that in secondary schools, school principals and administrators are responsible for preparation of the school budget and ensure effective financial management in order to achieve the objectives of the school. Modern technological apparatus are used in order to be more accountable for the income and expenditure of the school. MIS is used to prepare school budget and also carry a comprehensive financial audit. MIS facilitates the preparation of financial statements and provide a complete audit trail in order to facilitate audits (Karanja \& Ng'ang'a, 2014). School management utilizes MIS in the areas of payment of school fees, purchasing equipment, tracking unremitted fund, estimating the inflow and outflow of school fund at a given period among others. Through the use of computer and internet, students are able to pay for educational services like hostel fee, tuition fee, and transportation fee among others without necessary going to the school to make transaction. MIS provides bases for making quality financial decisions in enhancing school improvement. However, some school administrators find it difficult to account for the income and expenditure but prefer to shift blames to subordinates. In line with this, Magak (2013) summarized the challenges of school administrators in managing and deciding on school funds. This included incompetency in procurement, inadequate and irregular auditing, lack of accounting supportive documents and records and inability to prepare end year financial statements among others. The utilization of financial management information system enables school managers to accurately plan and forecast school cash inflow and outflow for the next fiscal year.

\section{Statement of the Problem}

The state of administrative activities in secondary schools in Enugu education zone is worrisome. It is believed that school principals who are the chief administrative officers are on the frontline of 
the battle to ensure a smooth and accountable administrative process in the school. personal observation of the researchers revealed cases of delay in processing students' results, poor students attendance monitoring and admission of new students, inability to identify students who default payment, misplacement of vital financial records among others in secondary schools in Enugu education zone. These challenges perhaps may be as a result of the inability principals' who are the chief administrators to utilize management information system to enhance smooth and uninterrupted administrative activities their respective schools. It is against this premise that this study aimed at ascertaining school administrators' utilization of management information system for administrative effectiveness in secondary schools in Enugu Education Zone.

\section{Purpose of the Study}

The main purpose of this study is to determine school administrators' utilization of management information system for administrative effectiveness in secondary schools in Enugu Education Zone.

Specifically, the study sought to ascertain:

1) School administrators' utilization of management information system for students' personnel administration in secondary schools in Enugu Education Zone

2) School administrators' utilization of management information system for financial management in secondary schools in Enugu Education Zone

\section{Research Questions}

The following research questions guided the study:

1) Do school administrators' utilize management information system for students' personnel administration in secondary schools in Enugu Education Zone?

2) Do school administrators' utilize management information system for financial management in secondary schools in Enugu Education Zone?

\section{Method}

The study adopted the descriptive survey design and was conducted in Enugu education zone in Enugu State. The target population of the study comprised all the 31 principals in public secondary schools in Enugu education zone. No sampling was employed in this study owing to the relatively small size of the population of the study. Hence, all the 31 principals in public secondary schools in Enugu education zone were used for the study. A 14 items researcher developed instrument titled; School Administrators' utilization Management Information System Questionnaire (SAMISQ) was used for data collection. The instrument was structured on a four rating scale of Strongly Agree (SA), Agree (A), Disagree (D) and Strongly Disagree (SD) weighted 4, 3, 2 and 1 respectively. The validation of the instrument was established by three experts, two from the Department of Educational Management and Policy and one from the Department of Educational Foundations (Measurement and Evaluation Unit), Faculty of Education, NnamdiAzikiwe University, Awka. The suggestions and inputs of the experts were reflected on the final draft of the instrument. The Cronbach alpha was used to determine the reliability of the instrument which yielded the coefficient values of 0.85 and 0.79 were obtained for part I and II respectively of SAMISQ. The overall coefficient value of 0.82 was considered high enough for the instrument 
usability. This is in line with Nworgu (2015) who recommended that co-efficient value of 0.60 or above is adequate for any research work. The instrument was administered by the researcher together with the help of three research assistants who were briefed on how to approach the respondents. Data were analyzed using mean and standard deviation. The mean responses were adjudged on the basis that any mean score of 2.50 or above is taken to indicate agreement while any mean score that falls below 2.50 is taken as disagreement.

\section{Results}

Research Question 1: Do school administrators' utilize management information system for students' personnel administration in secondary schools in Enugu Education Zone?

Table 1: School administrators' utilize management information system for students' personnel administration in secondary schools

\begin{tabular}{|l|l|l|l|l|}
\hline $\mathbf{S} / \mathbf{N}$ & Items & $\overline{\mathbf{X}}$ & $\mathbf{S D}$ & Decision \\
\hline 1 & Allowing students to apply for admission online & 1.67 & 0.18 & Disagree \\
\hline 2 & $\begin{array}{l}\text { Processing students results using spreadsheet } \\
\text { software }\end{array}$ & 2.21 & 0.45 & Disagree \\
\hline 3 & $\begin{array}{l}\text { Providing online means for students to pay } \\
\text { school fees }\end{array}$ & 2.70 & 0.58 & Agree \\
\hline 4 & $\begin{array}{l}\text { Managing students attendance using spreadsheet } \\
\text { software }\end{array}$ & 2.14 & 0.76 & Disagree \\
\hline 5 & $\begin{array}{l}\text { Disseminating information to students and } \\
\text { parent through the school website }\end{array}$ & 2.10 & 0.65 & Disagree \\
\hline 6 & $\begin{array}{l}\text { Preparing students result in spreadsheet } \\
\text { software application }\end{array}$ & 2.51 & 0.72 & Agree \\
\hline 7 & $\begin{array}{l}\text { Encouraging teachers to issue home assignment } \\
\text { to student using email system }\end{array}$ & 2.22 & 0.57 & Disagree \\
\hline 8 & $\begin{array}{l}\text { Encouraging multi-media instructional delivery } \\
\text { using PowerPoint software application }\end{array}$ & 1.50 & 0.69 & Disagree \\
\hline Mean of means and Standard Deviation & $\mathbf{2 . 1 3}$ & $\mathbf{0 . 5 8}$ & Disagree \\
\hline
\end{tabular}

Data analysis on Table 1 revealed that respondents agreed on items 3 and 6 . This is shown by mean ratings of the items that fall above the cut-off mean of 2.50. This implies that respondents agreed that school administrators' utilize management information system for students' personnel administration in secondary schools by providing online means for students to pay school fees and preparing students result in spreadsheet software application.

However, respondents disagreed on items 1, 2, 4, 57 and 8. This is shown by mean ratings of the items that fall below 2.50. This implies that respondents disagreed that school administrators' do not utilize management information system for students' personnel administration in secondary schools by not; allowing students to apply for admission online, processing students results using spreadsheet software, managing students attendance using spreadsheet software, disseminating information to students and parent through the school website, encouraging teachers to issue home assignment to student using email system, and encouraging multi-media instructional delivery using PowerPoint software application. The mean of means' value of 2.13 which falls below the 
cut-off mean score of 2.50 indicate disagreement on school administrators' utilize management information system for students' personnel administration in secondary schools. The standard deviation scores for all the items in the cluster are within the same range, indicating that the respondents are homogeneous in their responses.

Research Question 2: Do school administrators' utilize management information system for financial management in secondary schools in Enugu Education Zone?

Table 2: School administrators' utilize management information system for financial management in secondary schools

\begin{tabular}{|l|l|l|l|l|}
\hline S/N & Items & $\overline{\mathbf{X}}$ & $\mathbf{S D}$ & Decision \\
\hline 9 & $\begin{array}{l}\text { Keeping accurate account of all financial } \\
\text { transactions using spreadsheet application }\end{array}$ & 2.56 & 0.52 & Disagree \\
\hline 10 & $\begin{array}{l}\text { Drafting the school budget using a central } \\
\text { datatbase }\end{array}$ & 2.12 & 0.82 & Disagree \\
\hline 11 & $\begin{array}{l}\text { Using remita online payment gateway for } \\
\text { fees payment }\end{array}$ & 1.60 & 0.68 & Agree \\
\hline 12 & $\begin{array}{l}\text { Preparing the school statement of account using } \\
\text { operation support system }\end{array}$ & 2.14 & 0.50 & Disagree \\
\hline 13 & $\begin{array}{l}\text { Monitoring expenditure in the school using } \\
\text { central database }\end{array}$ & 2.70 & 0.65 & Disagree \\
\hline 14 & $\begin{array}{l}\text { Storing all financial information into a } \\
\text { storage devices }\end{array}$ & 2.46 & 0.71 & Agree \\
\hline Mean of means and Standard Deviation & $\mathbf{2 . 2 6}$ & $\mathbf{0 . 6 5}$ & Disagree \\
\hline
\end{tabular}

Data analysis on Table 2 revealed that respondents agreed on items 9 and 13. This is shown by mean ratings of the items that fall above the cut-off mean of 2.50. This implies that respondents agreed that school administrators' utilize management information system for financial management in secondary schools by keeping accurate account of all financial transactions using spreadsheet application and monitoring expenditure in the school using central database.

Nevertheless, respondents disagreed on items $10,11,12$ and 14 . This is shown by mean ratings of the items that fall below the cut-off mean of 2.50. This implies that respondents disagreed that school administrators' do not utilize management information system for financial management in secondary schools by not; drafting the school budget using a central datatbase, using remita online payment gateway for fees payment, preparing the school statement of account using operation support system and storing all financial information into storage devices. The mean of means' value of 2.26 which falls below the cut-off mean score of 2.50 indicate disagreement on school administrators' utilize management information system for financial management in secondary schools. The standard deviation scores for all the items in the cluster are within the same range, indicating that the respondents are homogeneous in their responses.

\section{Discussion}

Based on data analysis on Table 1, the study found out that school administrators' do not utilize management information system for students' personnel administration in secondary schools by 
not; allowing students to apply for admission online, processing students results using spreadsheet software, managing students attendance using spreadsheet software, disseminating information to students and parent through the school website, encouraging teachers to issue home assignment to student using email system, and encouraging multi-media instructional delivery using PowerPoint software application. This finding is in disagreement with the Benwari and Dambo (2014) who reported that school management information system are used for infrastructure and fees management, hostel space allocation and management, tracking students who have defaulted in payment of fees or other things.

The finding of this study also revealed that school administrators' do not utilize management information system for financial management in secondary schools by not; drafting the school budget using a central datatbase, using remita online payment gateway for fees payment, preparing the school statement of account using operation support system and storing all financial information into storage devices. This finding disagree with that of Akram (2011) who reported that there was high extent of management information system being utilized to support strategic planning for decision on financial matters. This contradiction may be as a result of difference in geographical location. Secondary school principals are expected to familiarize themselves with the use of modern and digital method of school administration so as to easily accomplish school objectives.

\section{Conclusion}

Management information system (MIS) becomes necessary when all administrative efforts proof ineffective to sustain the educational needs and aspirations of the learners. At the secondary facet of education, the administrative role of the principal is critical in ensuring the uninterrupted operation of the school through the introduction of digitalized approach. However, the study concluded based on the findings that school administrators' do not utilize management information system for students' personnel administration in secondary schools in Enugu Education Zone. Also,school administrators' do not utilize management information system for financial management in secondary schools in Enugu Education Zone.

\section{Recommendations}

The following recommendations were made based on the findings of the study:

1) The Government through the State Ministry of Education should organize seminars and workshop for secondary school administrators in order to train them on the utilization of management information system for student personnel administration.

2) School administrators at the secondary school level should also be exposed to the use of specific MIS software applications that are often used for financial transaction in order to avert constant financial loss, thus enhancing financial accuracy and accountability in the school administration.

\section{References}

[1] Akinfolarin, A.V. (2017). Time management strategies as a panacea for principals' administrative effectiveness in secondary schools in Enugu State, Nigeria. Journal for Studies in Management and Planning,3(9), 22-31. 
[2] Akinola, O.B. (2013). Principals' leadership skills and school effectiveness: The case of south western, Nigeria. World Journal of Education, 3(5), 26-33.

[3] Akomolafe, C.O. (2012). A comparative study of principals' administrative effectiveness in public and private secondary schools in Ekiti State, Nigeria. Journal of Education and Practice,3(13) 3945.

[4] Akpan, C. P. \&Onabe, D. B (2016). Management of students' personnel services and sustainable secondary education in calabar education zone of Cross River State, Nigeria. Global Journal of Human Resource Management 4, (3) 16-26.

[5] Akram, J.K. (2011). The significance of management information systems for enhancing strategic and tactical planning. Journal of Information Systems and Technology Management, 8(2), 459-470.

[6] Alia, C.O. \&Iwuoha, N.S. (2014). New challenges facing Imo State secondary school principals in a decentralized system: the way forward. Journal of Educational Research, 2(3), 179-187.

[7] Asiabaka, I. P. (2010). Access and use of information and communication technology (ICT) for administrative purposes by principals of government secondary schools in Nigeria. The Researcher, 2(1):43-50.

[8] Benwari, N.N. \&Dambo, B.I. (2014). Improving school management through transformational leadership approach and management information system. Journal of Education and Social Research, 4(6), 401-406.

[9] Egwu, S.O. (2016). Management strategies for conflict resolution in secondary schools in Ebonyi state, Nigeria. UNIZIK Journal of Educational Management and Policy, 1(1), 88-94.

[10] Ejeh, E. I., Okenjom, G. P. \&Chizi-Woko, C. N (2016). Management of student personnel services in Nigerian tertiary institutions. IOSR Journal of Research \& Method in Education, 6, (3), 1-6.

[11] Ikediugwu, N.P. (2016). Admintrative and managerial skills for effective secondary school management. UNIZIK Journal of Educational Management and Policy, 1(1), 1-7.

[12] Karanja, J.G. \&Ng'ang'a, E.N. (2014). Factors influencing implementation of financial management information system in Kenya government Ministries. Research Journal of Finance and Accounting, 5(7), 10-17.

[13] Madiha, S. (2013). Impact of management information system on school administration: What the literature says. Procedia-Social and Behavioural Sciences, 116(2014), 2799-2804.

[14] Magak, E.O. (2013). Challenges facing head teachers in financial management in public secondary schools: A case of Kisumu East District Kenya. Unpublished MEAP project, University of Nairobi, Kenya.

[15] Nwangwu, J.U., Ememe, O.N. \&Obike, C.N. (2013). Management information system as a technique in the administration of secondary schools in Aba zone, south east Nigeria. International Journal of learning and Development, 3(3), 194-202.

[16] Okon, J.E, Ekaette, S.O. \&Ameh, E (2015). Information and communication technology (ICT) utilization and principals' administrative effectiveness in public secondary schools in Akwalbom State, Nigeria. African Educational Research Journal,3(2),131-135.

\footnotetext{
*Corresponding author.

E-mail address: cthompson@ unizik.edu.ng/ on.anachuna@ unizik.edu.ng
} 